Authors' contribution/

Wkład autorów:

A. Zaplanowanie badań/

Study design

B. Zebranie danych/

Data collection

C. Analiza statystyczna/

Statistical analysis

D. Interpretacja danych/

Data interpretation

E. Przygotowanie tekstu/

Manuscript preparation

F. Opracowanie

piśmiennictwa/

Literature search

G. Pozyskanie funduszy/

Funds collection
ISSN 2083-3725

Volume 10, No. 4, 2017

\section{PRINCIPLES FOR RATING OF STATE AID AND DE MINIMIS AID IN REPAYABLE FINANCE}

\section{ZASADY OKREŚLANIA WARTOŚCI POMOCY PUBLICZNEJ I POMOCY DE MINIMIS W PRZYPADKU ZWROTNYCH INSTRUMENTÓW WSPARCIA}

\section{Dariusz Kowalski}

The Jan Kochanowski University in Kielce

Uniwersytet Jana Kochanowskiego w Kielcach

Kowalski D. (2017), Principles for rating of state aid and de minimis aid in repayable finance/ Zasady określania wartości pomocy publicznej i pomocy de minimis $w$ przypadku zwrotnych instrumentów wsparcia. Economic and Regional Studies, Vol. 10, No. 4, pp. 54-61. https://doi.org/10.29316/ers-seir.2017.34

\section{Summary}

Subject and purpose of work: The subject of the article is an analysis of the state aid rules by state authorities in the context of calculating the amount of state aid. This problem was discussed on the basis of a relatively new form of assistance repayable instruments. The aim of this article is to identify the noncompliance of the rules generally applicable to the rules for repayable support.

Materials and methods: In order to achieve the objectives set, the analysis of the identified problems was based on non-reactive research involving the assessment of available information. It included studies of normative acts, literature of the subject and reports and analyzes.

Results: It has been identified that the current form of act on State aid cases does not take into account the specific nature of aid calculation under return instruments, which is that the final value of the state aid is known only after the repayment of the financial instrument.

Conclusions: The legislator should adjust the law on proceedings in state aid cases, the more frequently used form of State intervention is repayable finance. The current practice differs from the literal wording of the provisions in question and should therefore be amended to adapt the provisions to this form of aid.

Keywords: de minimis aid, SMEs, state aid, repayable finance

\section{Streszczenie}

Przedmiot i cel pracy: Przedmiotem artykułu jest analiza zasad udzielania pomocy publicznej przez organy państwowe w kontekście obliczania jej wysokości. Problem ten został omówiony w oparciu o relatywnie nową formę pomocy tj. instrumenty zwrotne. Celem artykułu jest zidentyfikowanie braku zgodności przepisów powszechnie obowiązujących z zasadami udzielania wsparcia zwrotnego.

Materiały i metody: Aby osiągnąć założone cele, analiza wskazanych problemów oparta była na badaniach niereaktywnych, polegających na ocenie dostępnych informacji. Uwzględniała ona studia aktów normatywnych, literatury przedmiotu oraz branżowych raportów i analiz. W artykule jako podstawową wykorzystano metodę dogmatyczno-prawną skutkującą krytyczną analizą przepisów prawa.

Wyniki: Zidentyfikowano, iż obecna forma ustawy o postępowaniu w sprawach dotyczących pomocy publicznej nie uwzględnia specyficznej cechy obliczania pomocy w ramach instrumentów zwrotnych, jaką jest fakt, że ostateczna wartość pomocy znana jest dopiero po całkowitej spłacie instrumentu finansowego.

Wnioski: Ustawodawca powinien dostosować wskazaną ustawę do coraz częściej stosowanej formy interwencji państwa, jaką jest pomoc zwrotna. Obecna praktyka odbiega od literalnego brzmienia wskazanych przepisów, dlatego w celu dostosowania przepisów do tej formy pomocy powinny one zostać zmienione.

Słowa kluczowe: pomoc de minimis, MŚP, pomoc publiczna, wsparcie zwrotne

Address for correspondence/ Adres korespondencyjny: dr Dariusz Kowalski, UniwersytetJana Kochanowskiego w Kielcach, Wydział Prawa Administracji i Zarządzania, Zakład Polityki Gospodarczej i Systemów Bankowych, ul. Świętokrzyska 21, 25-406 Kielce, Polska; tel.: +48 5189390 47, e-mail: dk23111@ wp.pl; ORCID 0000-0003-3864-4568.

Journal indexed in/ Czasopismo indeksowane w: AgEcon Search, AGRO, BazEkon, Index Copernicus Journal Master List, ICV 2016: 92,91; Polish Ministry of Science and Higher Education 2016: 9 points / AgEcon Search, AGRO, BazEkon, Index Copernicus Journal Master List ICV 2016: 92.91; Ministerstwie Nauki i Szkolnictwa Wyższego 2016: 9 punktów. Copyright: (c) 2017 Pope John Paul II State School of Higher Education in Biała Podlaska, Dariusz Kowalski. All articles are distributed under the terms of the Creative Commons Attribution-NonCommercial-ShareAlike 4.0 International (CC BY-NC-SA 4.0) License (http://creativecommons.org/licenses/by-nc-sa/4.0/), allowing third parties to copy and redistribute the material in any medium or format and to remix, transform, and build upon the material, provided the original work is properly cited and states its license. 


\section{Introduction}

One of the fundamental pillars of the European Union (EU) economic policy is to protect competition between enterprises operating in the EU. According to article 107 of the Treaty on European Union, state aid is granted by a member state or through state resources in any form whatsoever which distorts or threatens to distort competition.

In the indicated provision, state aid was banned. Legislative acts of a lex specialis nature in relation to the Treaty on the Functioning of the European Union are: Commission Regulation (EU) No 651/2014 of 17 June 2014 declaring certain types of aid compatible with the internal market pursuant to article 107 and 108 of the Treaty, and Commission Regulation (EU) No 1407/2013 on the application of articles 107 and 108 of the Treaty on the Functioning of the European Union to de minimis aid.

In view of the above - although in principle the state cannot support free market players - under certain conditions, Member State aid may be granted to private parties. The subject of this article is an analysis of one of the aspects of this assistance, which is to calculate its amount in relation to a relatively new form of support, ie repayable finance.

The purpose of this article is to identify the noncompliance of the rules generally applicable to the rules for repayable finance. In order to achieve the objective, the analysis of the identified problems was based on research involving the assessment of available information. It included studies of normative acts, subject literature and industry reports and analyzes. For the purposes of this paper, the following research hypothesis has been adopted: The current provisions on the de minimis aid rules in back support instruments are imprecise, resulting in legal uncertainty for the applicants.

\section{Repayable instruments}

One of the important instruments for optimization the management of public funds is repayable financing. Such a model of public support is characterized by flexibility, the occurrence of capital multiplier effects, and the revolving of financial resources. Repayable financing is understood as support in the form of instruments allowing beneficiaries to obtain the cash that they will be required to repay. Once these funds have been repayable, they will be re-used to support the next enterprices. In this type of financing, public funds can be used directly, eg in the form of loans, credits or equity instruments (debt instruments)

\section{Wstęp}

Jednym z podstawowych filarów polityki gospodarczej Unii Europejskiej (UE) jest ochrona konkurencji pomiędzy przedsiębiorstwami działającymi na jej terenie. Zgodnie $\mathrm{z}$ art. 107 Traktatu o funkcjonowaniu Unii Europejskiej, pomoc przyznawana przez państwo członkowskie lub przy użyciu zasobów państwowych w jakiejkolwiek formie, która zakłóca lub grozi zakłóceniem konkurencji poprzez sprzyjanie niektórym przedsiębiorstwom, jest niezgodna $\mathrm{z}$ rynkiem wewnętrznym w zakresie, w jakim wpływa na wymianę handlową między państwami członkowskimi.

We wskazanym przepisie wprost zakazano pomocy państwa. Aktami normatywnymi mającymi charakter lex specialis w stosunku do Traktatu o funkcjonowaniu Unii Europejskiej są: rozporządzenie Komisji (UE) nr 651/2014 z dnia 17 czerwca 2014 r., uznające niektóre rodzaje pomocy za zgodne $\mathrm{z}$ rynkiem wewnętrznym w zastosowaniu art. 107 i 108 Traktatu, oraz rozporządzenie Komisji (UE) nr 1407/2013 w sprawie stosowania art. 107 i 108 Traktatu o funkcjonowaniu Unii Europejskiej do pomocy de minimis.

W związku z powyższym - pomimo iż co do zasady państwo nie może wspierać podmiotów działających na wolnym rynku - w określonych warunkach dopuszczalna jest pomoc państwa członkowskiego na rzecz podmiotów prywatnych. Przedmiotem niniejszego artykułu jest analiza jednego z aspektów udzielania tej pomocy, jakim jest obliczanie jej wysokości w odniesieniu do relatywnie nowej formy wsparcia, tj. do pomocy zwrotnej.

Celem artykułu jest zidentyfikowanie braku zgodności przepisów powszechnie obowiązujących z zasadami udzielania wsparcia zwrotnego. Aby osiągnąć założony cel, analiza wskazanych problemów oparta była na badaniach niereaktywnych, polegających na ocenie dostępnych informacji. Uwzględniała ona studia aktów normatywnych, literatury przedmiotu oraz branżowych raportów i analiz. W artykule jako podstawową wykorzystano metodę dogmatyczno-prawną, skutkującą krytyczną analizą przepisów prawa. Na potrzeby niniejszej pracy przyjęto następującą hipotezę badawczą: Obecne przepisy w zakresie zasad udzielania pomocy de minimis $w$ ramach zwrotnych instrumentów wsparcia są nieprecyzyjne, co powoduje brak pewności prawnej u podmiotów je stosujących.

\section{Instrumenty zwrotne}

Jednym z nowszych instrumentów racjonalizacji gospodarowania środkami publicznymi jest finansowanie inwestycji o charakterze zwrotnym. Taki model publicznego wsparcia cechuje duża elastyczność, występowanie efektu mnożnika kapitałowego oraz rewolwingu środków finansowych, dzięki czemu pomoc $w$ tej formie przyczynia się do efektywniejszego wykorzystania środków publicznych. W tym miejscu należy zaznaczyć, że przez finansowanie zwrotne rozumie się wsparcie $w$ postaci instrumentów pozwalających na uzyskanie przez beneficjentów środków pieniężnych, które będą zobowiązane zwrócić na określonych warunkach. Po zwrocie tych środków będą one ponownie 
or indirectly eg through the provision of bank guarantees (guarantee instruments) (Kowalski 2014).

It should be noted that such support should only be provided where there is a so-called financial gap, which means that no part of the enterprise is able to obtain funds on the commercial financial market. Activity of the state should not be competitive in relation to commercial financing. This activity should only fill the financial gap in areas where market-based financing is not available, for example due to low creditworthiness.

\section{Increase in importance of repayable instruments in 2014-2020}

Taking into account the indicated advantages of returnable financial instruments, the coordinators implementing the EU funds have decided to increase the importance of these forms of support in the operational programs implemented under the EU 2014-2020 programming. It was assumed that $15 \%$ of the total funds allocated for the period 20142020 (Konopielko 2015) could be allocated to such instruments. At the same time it should be noted that the current share of such instruments in regional policy was estimated at around 2\% (Lepczyński, Penczar 2013). By transferring these estimates to enterprise development programs, regional operational programs within the framework of the JEREMIE initiative can be cited as an example. In the EU programming period 2007-2013, Bank Gospodarstwa Krajowego managed as a six holding founds JEREMIE with the amount of nearly PLN 1.76 billion. Under the same six voivodships, 2014-2020 was allocated to repayable instruments for SMEs close to PLN 3.16 billion, which constitutes almost $180 \%$ of the amount dedicated to these instruments in the years 2007-2013. wykorzystane na wsparcie kolejnych beneficjentów. Odnawialna forma wsparcia powoduje zwiększenie faktycznie transferowanych środków. Z samej specyfiki tego rodzaju instrumentów wynika, że niemożliwym jest objęcie nimi wszystkich rodzajów wydatków publicznych. Model ten może zostać zastosowany tam, gdzie środki publiczne pełnią funkcję swoistego katalizatora inicjującego inwestycje, które nie mogłyby zostać zrealizowane na warunkach rynkowych. W tego typu finansowaniu środki publiczne moga być wykorzystane bezpośrednio np. w postaci pożyczek, kredytów lub instrumentów o charakterze kapitałowym (instrumenty dłużne) albo w sposób pośredni, np. poprzez udzielenie poręczeń i gwarancji bankowych (instrumenty poręczeniowe), dzięki czemu beneficjent będzie miał możliwość uzyskania wsparcia na rynku komercyjnym (Kowalski 2014).

Należy zaznaczyć, że wsparcie takie powinno być realizowane wyłącznie $\mathrm{w}$ przypadku, gdy występuje tak zwana luka finansowa, która oznacza, że część przedsiębiorstw nie ma możliwości uzyskania środków na komercyjnym rynku finansowym. Należy podkreślić, że działalność państwa nie powinna mieć charakteru konkurencyjnego w stosunku do finansowania komercyjnego. Działalność taka powinna jedynie wypełniać lukę finansową w obszarach, w których finansowanie na zasadach rynkowych jest niedostępne, np. ze względu na niską zdolność kredytową przedsiębiorstw czy wczesny etap ich działalności (start up).

\section{Wzrost znaczenia instrumentów zwrotnych $\mathrm{w}$ la- tach 2014-2020}

Biorąc pod uwagę wskazane zalety zwrotnych instrumentów finansowych, podmioty koordynujące wdrażanie środków UE podjęły kierunkowe decyzje o wzroście znaczenia tych form wsparcia w programach operacyjnych realizowanych $w$ ramach programowania unijnego 2014-2020. Zakładano możliwość przeznaczenia na tego rodzaju instrumenty $15 \%$ całości funduszy przeznaczonych na lata 2014-2020 (Konopielko 2015). Jednocześnie należy zaznaczyć, że dotychczasowy udział tego rodzaju instrumentów $w$ polityce regionalnej szacowany był na poziomie około 2\% (Lepczyński, Penczar 2013). Przenosząc wskazane szacunki na grunt programów dedykowanych na rzecz rozwoju przedsiębiorstw, można jako przykład przytoczyć regionalne programy operacyjne, w ramach których wdrażano inicjatywę JEREMIE. W programowaniu unijnym w latach 2007-2013 podmiotem koordynującym zwrotne wsparcie $w$ ramach inicjatywy JEREMIE był Bank Gospodarstwa Krajowego. Zarządzał on jako menadżer sześciu funduszy powierniczych JEREMIE (województwa: dolnośląskie, łódzkie, mazowieckie, pomorskie, wielkopolskie i zachodniopomorskie) kwotą blisko 1,76 mld zł. W ramach tych samych sześciu województw w latach 2014-2020 powierzono na zwrotne instrumenty dla MŚP blisko 3,16 mld zł, co stanowi blisko $180 \%$ kwoty przeznaczonej na te instrumenty w latach 2007-2013. 


\section{Repayable financing and State Aid}

Explanation requires the identification of repayable support with public aid. In the literature of the subject, repayable support and public aid (including de minimis aid) are used interchangeably (Gancarczyk 2010). It should be stressed, however, that in fact these concepts cannot be identified. In the case of loans, sureties and guarantees, the aid granted to the entrepreneur is not considered to be public aid if the price for granting it does not differ from market conditions. Determining whether the aid is market-based is in accordance with the rules laid down in the relevant legislation at EU level.

It is important to point out that the definition of aid rules (in particular assumption or support should be marketable or aid) is extremely important. If the aid is distributed on terms more favorable than market, the beneficiaries of the aid may decide to seek support not on the basis of their willingness to develop, and on the basis of their willingness to benefit. This may lead to the situation that the support will be used by entrepreneurs who would be able to obtain funds in the financial market. State support in this case will not fill the financial gap and will be a competition for financial institutions. Thus, the basic premise of applying market conditions with the support of beneficiaries is that, under such a support mode, only those affected by the financial gap will decide to get support.

\section{Calculating the value of state aid for repayable instruments}

The specific aspects for repayable instruments are the calculation of the value of state aid granted in this form. Determination of such rules is important in determining whether the aid meets the condition of state aid, and if it fulfills this, does the aid exceed the thresholds specified for de minimis aid. Fundamental regulations in this area are the Communication from the Commission on the revision of the method for setting the reference and discount rates and the Commission Notice on the application of Articles 87 and 88 of the EC Treaty to state aid in the form of guarantees.

According to the Communication, to determine whether financial support is State aid, you should compare the interest rate of the support received

\section{Instrumenty zwrotne a pomoc publiczna}

Wyjaśnienia wymaga kwestia utożsamiania wsparcia zwrotnego z pomocą publiczną. W literaturze przedmiotu wsparcie zwrotne oraz pomoc publiczna (w tym pomoc de minimis) są używane zamiennie (Gancarczyk 2010). Należy jednak podkreślić, że w rzeczywistości nie można tych pojęć utożsamiać ze sobą. W przypadku pożyczek kredytów, poręczeń i gwarancji pomoc udzielaną przedsiębiorcy nie uznaje się za pomoc publiczną (również nie będzie uznana za pomoc de minimis) w przypadku, gdy cena za jej udzielenie nie będzie odbiegała od warunków rynkowych. Określenie, czy dana pomoc ma charakter rynkowy, odbywa się zgodnie z regułami określonymi we właściwych przepisach na poziomie regulacji UE. Pomimo to, należy podkreślić, że wsparcie beneficjentów ze środków publicznych na zasadach rynkowych stanowi obecnie marginalną ilość w stosunku do całego udzielonego wsparcia.

Należy zaznaczyć, że określenie zasad udzielania pomocy jest niezwykle istotne - w szczególności przyjęcie założeń, czy wsparcie powinno mieć charakter rynkowy, czy powinno stanowić pomoc. Jeśli pomoc będzie dystrybuowana na warunkach korzystniejszych niż rynkowe, beneficjenci pomocy mogą podejmować decyzje o pozyskaniu wsparcia nie z uwagi na chęć rozwoju, a z uwagi na chęć uzyskania korzyści. Może to doprowadzić do sytuacji, w której ze wsparcia będą korzystali przedsiębiorcy, którzy byliby w stanie uzyskać środki na rynku finansowym. Wsparcie państwa w takim przypadku nie będzie wypełniało luki finansowej, a będzie stanowiło konkurencję dla instytucji finansowych. Tak więc podstawową przesłanką stosowania warunków rynkowych przy wsparciu beneficjentów jest założenie, że przy takim trybie wsparcia tylko podmioty objęte luką finansową będą decydowały się na uzyskanie pomocy.

Przykładem działania na zasadach korzystniejszych niż rynkowe są w szczególności instrumenty dotacyjne (finansowanie bezzwrotne przedsiębiorstw, np. w formie dotacji), które powinno zostać ograniczone do działań państwa w ramach polityki przeciwdziałania bezrobociu lub w ramach badań wysoce innowacyjnych.

\section{Obliczanie wartości pomocy publicznej dla instru- mentów zwrotnych}

Działaniem specyficznym dla instrumentów zwrotnych są zasady obliczania wartości pomocy publicznej udzielanej w tej formie. Określenie takich zasad ma znaczenie dla ustalenia, czy dana pomoc spełnia przesłanki pomocy publicznej, a jeśli je spełnia, to czy ekwiwalent takiej pomocy przekracza progi określone dla pomocy udzielanej na zasadach de minimis. Podstawowymi regulacjami w tym zakresie są Komunikat Komisji w sprawie zmiany metody ustalania stóp referencyjnych i dyskontowych oraz Obwieszczenie Komisji w sprawie zastosowania art. 87 i 88 Traktatu WE do pomocy państwa w formie gwarancji. Zgodnie z komunikatem, aby określić, czy wsparcie finansowe stanowi pomoc państwa, należy porównać wysokość oprocentowania $\mathrm{w}$ ramach otrzymanego 
with the reference rate. If the support rate is higher, it means that it is granted on market terms and does not constitute aid. The reference rate is depends on two variables, ie the level of collateral and the category of rating indicating the entrepreneur's financial situation.

The base rate is published for each country every year. In addition, to take account of significant and sudden changes, the update is performed whenever the average rate calculated for the preceding three months exceeds the applicable rate by more than $15 \%$. This update took place in first and in the second quarter of 2013. In the case of guarantee instruments, the provisions of Commission Regulation (EC) No 1407/2013 of 18 December 2013 on the application of Articles 107 and 108 of the Treaty on the Functioning of the European Union to de minimis aid, and the Commission notice indicated. The notice specifies what the rates of commissions for granting the guarantee are the threshold for state aid. The threshold depends on the rating of the entrepreneur. If support is considered public aid, the value of the grant equivalent can be calculated on the basis of art. 4 of Regulation 1407/2013 in a simplified way. Simplified support may be granted if the aid is transparent, which means that:

- the beneficiary is not subject to collective insolvency proceedings nor fulfils the criteria under its domestic law for being placed in collective insolvency proceedings at the request of its creditors. In case of large undertakings, the beneficiary shall be in a situation comparable to a credit rating of at least $\mathrm{B}$-; and

- (b) the loan is secured by collateral covering at least $50 \%$ of the loan and the loan amounts to either EUR 1000000 (or EUR 500000 for undertakings performing road freight transport) over five years or EUR 500000 (or EUR 250000 for undertakings performing road freight transport) over 10 years; if a loan is for less than those amounts and/or is granted for a period of less than five or 10 years respectively, the gross grant equivalent of that loan shall be calculated as a corresponding proportion of the relevant ceiling laid down in Article 3(2);

It should be noted that in the Polish language version of Regulation 1407/2013, in the provisions on the applicability of the simplified formula for the calculation of the grant equivalent, the underlying transaction is exclusively a loan. Taking into account the specificity of the Polish legal system, where "pożyczki" and "kredyty" are separate legal institutions, this specificity should be taken into account in regulation 1407/2013 so that SMEs can equally benefit from both "pożyczek" and "kredytów". This gap contributes to the different, frequently contradictory interpretation of this provision by the various de minimis aid providers. It is advisable to indicate a broader directory of returnable financing instruments whose purpose and principles are similar or similar to the loan while maintaining the maximum amounts and duration of the guarantee. wsparcia ze stopą referencyjną. Jeżeli oprocentowanie wsparcia jest wyższe, oznacza to, że udzielone zostało na zasadach rynkowych i nie stanowi pomocy. Stopa referencyjna obliczana jest poprzez dodanie do jednorocznej stopy bazowej marży, której wysokość uzależniona jest od dwóch zmiennych, tj. od poziomu zabezpieczeń oraz kategorii ratingowej oznaczającej sytuację finansową przedsiębiorcy. Stopa bazowa publikowana jest dla danego państwa co roku. Dodatkowo, w celu uwzględnienia znacznych i nagłych zmian, aktualizacja jest przeprowadzana każdorazowo, gdy średnia stopa obliczona za trzy poprzednie miesiące będzie odbiegać o więcej niż 15\% od stopy obowiązującej. Aktualizacja taka miała miejsce w I i II kwartale 2013 r. W przypadku instrumentów gwarancyjnych przy określaniu wartości pomocy publicznej zastosowania mają przepisy rozporządzenia Komisji (WE) nr 1407/2013 z dnia 18 grudnia 2013 r., w sprawie stosowania art. 107 i 108 Traktatu o Funkcjonowaniu Unii Europejskiej do pomocy de minimis oraz wskazywane obwieszczenia Komisji. W obwieszczeniu podano, jakie stawki prowizji za udzielenie gwarancji stanowią próg pomocy publicznej. Wysokość progów uzależniona jest od ratingu danego przedsiębiorcy. Jeśli wsparcie zostanie uznane za pomoc publiczną, wartość ekwiwalentu dotacji można obliczyć na podstawie art. 4 rozporządzenia 1407/2013 w sposób uproszczony. Wsparcie $\mathrm{w}$ formie uproszczonej może zostać przyznane, jeśli pomoc jest przejrzysta, co oznacza, że:

- beneficjent nie jest przedmiotem zbiorowego postępowania upadłościowego lub nie spełnia określonych właściwym dla niego prawem krajowym kryteriów objęcia zbiorowym postępowaniem upadłościowym na wniosek wierzycieli; oraz

- gwarancja nie przekracza 80\% wartości pożyczki bazowej oraz gwarantowana kwota wynosi 1500000 EUR (lub, w przypadku przedsiębiorstw zajmujących się transportem drogowym towarów, 750000 EUR) i czas trwania gwarancji wynosi pięć lat, albo gwarantowana kwota wynosi 750000 EUR (lub, w przypadku przedsiębiorstw zajmujących się transportem drogowym towarów, 375000 EUR) i czas trwania gwarancji wynosi dziesięć lat; jeżeli gwarantowana kwota jest niższa niż te kwoty lub gwarancji udzielono na okres krótszy niż odpowiednio pięć albo dziesięć lat.

Należy zauważyć, że $\mathrm{w}$ polskiej wersji językowej rozporządzenia 1407/2013 w przepisach dotyczących możliwości stosowania uproszczonej zasady obliczania ekwiwalentu dotacji transakcją bazową jest wyłącznie pożyczka. Biorąc pod uwagę specyfikę polskiego porządku prawnego, w którym pożyczki oraz kredyty dla MŚP są odrębnymi instytucjami prawnymi, należy uwzględnić tę specyfikę w rozporządzeniu 1407/2013, tak aby MŚP na równych zasadach mogły korzystać zarówno z pożyczki, jak i kredytu. Ponadto, zasadne jest rozszerzenie stosowania tej zasady przy gwarancjach, w których transakcją bazową jest zwrotny instrument finansowania w postaci leasingu. Wskazanie $\mathrm{w}$ polskiej wersji językowej rozporządzenia 1407/2013 literalnie jedynie pożyczki jako transakcji 


\section{Aid amount and de minimis aid certificate}

Turning to another problem of this article, that is the problem in determining the value of public aid received by beneficiaries under repayable instruments under Polish law, the basic legal provisions governing this area should be approximated.

Based on Article 5 sec. 3 of the Act of 30 April 2004 on proceedings in state aid cases, the aid providers shall issue to the beneficiary a certificate stating that the granted state aid is de minimis aid or de minimis aid in agriculture or fisheries. Accordingly, at the time of granting public aid, the donor authority should calculate its value and issue a specific certificate. It should be noted, however, that, according to the calculation of the value of aid for return instruments, the basis for calculation of the aid value may change over time (base rate, beneficiary rating, financing period, etc.). Therefore, the de facto ultimate value of the aid is known only after the entire instrument has been repaid. Unfortunately, the provisions of the Act on Public Assistance do not provide for such a situation, and there is doubt as to whether and if possible how to take account of changes in the facts affecting the change in the value of aid granted to the beneficiaries.

According art. $5 \mathrm{sec}$. 3 a of the indicated law, to this provision, where the value of the de minimis aid actually granted is different from the aid value indicated in the certificate issued, the grantor shall, within 14 days of the date on which it is established, issue a new certificate indicating the appropriate aid value and Declares the validity of the previous certificate invalid. This means that, in the case of a base rate change, for example, the aid authority should issue an amendment to the aid declaration to each beneficiary.

In practice, such corrections do not take place and their application could be a significant burden for the aid bodies because large aid projects would have to issue a significant number of such certificates (eg within the de minimis aid program implemented by Bank Gospodarstwa Krajowego under repayment assistance instruments) As of 31st of December bazowej, w ramach której można stosować uproszczoną zasadę, powoduje lukę w stosunku do pozostałych zwrotnych instrumentów finansowych. Luka ta przyczynia się do różnego, często sprzecznego interpretowania tegoż przepisu przez poszczególne podmioty udzielające pomocy de minimis. Zasadne jest wskazanie szerszego katalogu zwrotnych instrumentów finansowania, których cel i zasady są zbliżone lub podobne do pożyczki przy zachowaniu maksymalnych kwot i czasu trwania gwarancji. Jest to tym bardziej uzasadnione, że w przypadku niektórych projektów realizowanych przez Europejski Fundusz Inwestycyjny w ramach inicjatywy JEREMIE pomoc de minimis udzielana jest $w$ formie poręczeń, gdzie transakcję bazową stanowią transakcje leasingu.

\section{Wysokość pomocy a zaświadczenia o pomocy de minimis}

Przechodząc do kolejnego problemu niniejszego artykułu, czyli problemu w określeniu wartości pomocy publicznej uzyskanej przez beneficjentów w ramach instrumentów zwrotnych na gruncie przepisów prawa polskiego, należy przybliżyć podstawowe przepisy prawne regulujące ten obszar.

Na podstawie art. 5 ust. 3 ustawy z dnia 30 kwietnia 2004 r. o postępowaniu w sprawach dotyczących pomocy publicznej, podmioty udzielające pomocy wydają beneficjentowi pomocy zaświadczenie stwierdzające, że udzielona pomoc publiczna jest pomocą de minimis albo pomocą de minimis w rolnictwie lub rybołówstwie. Zgodnie z powyższym, w momencie udzielenia pomocy publicznej organ jej udzielający powinien obliczyć jej wartość i wydać określone zaświadczenie. Należy jednak zauważyć, że zgodnie z zasadami obliczania wartości pomocy dla instrumentów zwrotnych, podstawa obliczenia wartości pomocy może ulegać zmianom w czasie (wartość stopy bazowej, rating beneficjenta, okres finansowania itp.). Dlatego de facto ostateczna wartość pomocy znana jest dopiero po spłaceniu całego instrumentu. Niestety, przepisy ustawy o postępowaniu w sprawach dotyczacych pomocy publicznej nie przewidują takiej sytuacji i powstaje wątpliwość, czy (i ewentualnie w jaki sposób) uwzględniać zmiany okoliczności faktycznych mających wpływ na zmianę wartości pomocy udzielonej beneficjentom.

Odpowiedź na pytanie, czy takie zmiany powinny być uwzględniane, pośrednio można uzyskać, analizując art. 5 ust. 3a wskazanej ustawy. Zgodnie z tym przepisem, w przypadku gdy wartość faktycznie udzielonej pomocy de minimis jest inna niż wartość pomocy wskazana $\mathrm{w}$ wydanym zaświadczeniu, podmiot udzielający pomocy $\mathrm{w}$ terminie $14 \mathrm{dni}$ od dnia stwierdzenia tego faktu wydaje nowe zaświadczenie, w którym to wskazuje właściwą wartość pomocy oraz stwierdza utratę ważności poprzedniego zaświadczenia. Oznacza to, że w przypadku np. zmiany stopy bazowej organ udzielający pomocy powinien każdemu beneficjentowi wystawić korektę oświadczenia o pomocy.

W praktyce takie korekty nie maja miejsca, a ich stosowanie mogłoby być znacznym obciążeniem dla 
2016, over 118,000 businesses received help.)

In addition, there are doubts as to how the rules for calculating aid should be adjusted in the event of an adjustment:

1. Should the data (affecting the correction, eg base rate) for the calculation of aid be calculated separately for the period before the correction and after adjustment?

2. Do you include data from the correction date?

3. Should the change be based on suspension of repayment of the primary instrument, should the extension of the crediting period be extended or should only the repayment period be taken into account?

4. In addition, is there a question as to whether the value of the aid at the end of the repayment of the aid instrument should be verified each time?

The above catalog of doubts is an example. Accordingly, it seems reasonable to introduce the rules on the calculation of aid in the case of return instruments into the Act on public aid cases. In these rules, it is justified to adopt a simplification to limit the issue of corrections to situations dependent solely on the beneficiaries. This simplification would avoid the need for mass correction in the event of, for example, changing the base rate. Such simplification is necessary in view of the costs and labor required to assume that corrections should be made on a case-by-case basis.

At the same time it is legitimate to maintain the possibility of making adjustments if the change results from the actions of the beneficiary eg change of the crediting period. This will avoid situations in which beneficiaries could make adjustments beneficial to themselves in order to reduce the actual value of the aid (eg could conclude shorter credit terms and then append them to extend them). In the case of adjustments, the value of the aid granted should be separately calculated up to and after the adjustment period. organów udzielających pomoc, ponieważ w przypadku dużych projektów pomocowych należałoby wystawić znaczną liczbę takich zaświadczeń (np. w ramach programu pomocy de minimis realizowanego przez Bank Gospodarstwa Krajowego w ramach instrumentów pomocy zwrotnej według stanu na 31 grudnia $2016 \mathrm{r}$. pomoc uzyskało ponad 118 tys. przedsiębiorstw).

Dodatkowo powstają wątpliwości, jakie zasady obliczania pomocy przyjąć w przypadku konieczności dokonania korekty:

1. Czy dane (mające wpływ na korektę, np. stopa bazowa) do obliczenia pomocy powinny być liczone odrębnie dla okresu sprzed korekty i po korekcie?

2. Czy uwzględniać dane z dnia korekty?

3. Czy w przypadku jeżeli zmiana będzie polegać na zawieszeniu spłaty instrumentu pierwotnego, powinno się uwzględniać wydłużenie okresu kredytowania, czy powinien być uwzględniony jedynie okres spłaty instrumentu?

4. Dodatkowo powstaje pytanie, czy każdorazowo powinno weryfikować się wartość pomocy na koniec spłaty instrumentu pomocowego?

Wskazany powyżej katalog wątpliwości ma charakter przykładowy. W praktyce wątpliwości może powstać o wiele więcej, co wynika z faktu, iż zmiany okoliczności mających wpływ na wartość pomocy mogą obejmować kilka czynników (np. zmiana okresu spłaty instrumentu oraz zmiana ratingu beneficjenta).

W związku z powyższym uzasadnione wydaje się wprowadzenie do ustawy o postępowaniu w sprawach dotyczących pomocy publicznej reguł określających zasady obliczania pomocy w przypadku instrumentów zwrotnych. W regułach tych zasadnym jest przyjęcie uproszczenia pozwalającego ograniczyć wydawanie korekt do sytuacji zależnych jedynie od beneficjentów. Uproszczenie takie pozwoliłoby uniknąć konieczności masowego dokonywania korekt, w przypadku gdy ulega np. zmianie stopa bazowa. Uproszczenie takie jest niezbędne z uwagi na koszty i pracochłonność przyjęcia założenia, że korekty powinny być dokonywane każdorazowo.

Jednocześnie istotne jest utrzymanie możliwości dokonania korekt, jeśli zmiana wynika z działań beneficjenta - np. zmiana okresu kredytowania. Pozwoli to na uniknięcie sytuacji, w których beneficjenci mogliby dokonywać korekt korzystnych dla siebie w celu zmniejszenia faktycznej wartości pomocy (np. beneficjent mógłby zawierać umowy na krótszy okres kredytowania, a następnie aneksować w celu ich wydłużenia). W przypadku dokonywania korekt powinno się odrębnie obliczać wartość udzielonej pomocy do czasu dokonania korekty oraz po tym okresie.

Wskazane postulaty mają charakter otwarty, należy jednak podkreślić wagę problemu, ponieważ, jak wskazano, finansowanie zwrotne stanowi obecnie coraz bardziej znaczny instrument realizacji polityki gospodarczej państwa. Brak przejrzystości tych przepisów w zakresie instrumentów zwrotnych nie sprzyja ogólnemu dążeniu do uproszczenia zasad prowadzenia działalności gospodarczej. 


\section{Conclusions}

By going to the summary of article, I must to point out that there has been a steady increase in the importance of repayable instruments in state policy, while at the same time the legislature's inadequate legislative activity to adapt to this form of aid. It seems that the cause of this condition is, among other things. Low transparency of the rules governing this area.

In order to guarantee the beneficiaries the transparency of the regulations in this aspects, it is necessary to adjust the rules concerning the calculation of the state aid. Under the national legislation, the basic act requiring adaptation to this kind of support is the Act on Public Assistance Matters. The current form of this law does not take into account the specific nature of the calculation of aid under repayable instruments, which is the fact that the final value of the aid is known only after the full repayment of the financial instrument. The current practice of providing support differs from the literal wording of the provisions in question. Therefore, in order to adapt the rules to economic practice, they should be changed.

\section{Zakończenie}

Przechodząc do podsumowania niniejszego artykułu, należy pozytywnie odpowiedzieć na postawioną tezę badawczą i podkreślić stały wzrost znaczenia instrumentów zwrotnych $\mathrm{w}$ polityce państwa przy jednoczesnej niedostatecznej aktywności prawodawcy w zakresie dostosowania przepisów prawnych do tej formy pomocy. Wydaje się, że przyczyną tego stanu rzeczy jest m.in. mała przejrzystość norm regulujących ten obszar, a także nierozdzielenie zasad regulujących finansowanie oparte na dotacjach oraz zasad normujących wsparcie zwrotne. W celu zagwarantowania beneficjentom pomocy przejrzystości przepisów w tym zakresie niezbędnym jest dostosowanie regulacji dotyczących zasad obliczania wysokości pomocy publicznej.

Na gruncie przepisów krajowych podstawowym aktem wymagającym dostosowania do tego rodzaju wsparcia jest ustawa o postępowaniu w sprawach dotyczących pomocy publicznej. Obecna forma tej ustawy nie uwzględnia specyficznej cechy obliczania pomocy w ramach instrumentów zwrotnych, jaką jest fakt, iż ostateczna wartość pomocy znana jest dopiero po całkowitej spłacie instrumentu finansowego. Obecna praktyka udzielania wsparcia odbiega od literalnego brzmienia wskazanych przepisów. Dlatego w celu dostosowania przepisów do praktyki gospodarczej powinny one zostać zmienione.

\section{References/Literatura:}

1. Dokument roboczy nr 207 Banku Rozrachunków Międzynarodowych.

2. Gajewski M., Szczucki J. (2013), Ekspertyza nt. dobrych praktyk $w$ zakresie rozwiązywania problemów w dostępie do finansowania zwrotnego w wybranych krajach Europy, w tym w państwach regionu Europy Środkowo-Wschodniej. PARP, Warszawa.

3. Gancarczyk M. (2010), Wsparcie publiczne dla MŚP Podstawy teoretyczne a praktyka gospodarcza. C.H. Beck, Warszawa.

4. Klonowski D. (2009), Innowacyjność sektora MŚP w Polsce Rządowe programy wsparcia a luka finansowa. Ernst \& Young Polska, Warszawa.

5. Konopielko Ł. (2015), Zwrotne instrumenty wsparcia w nowej perspektywie finansowej UE. Płock.

6. Kowalski D. (2012), Finansowanie zwrotne jako instrument racjonalizacji gospodarowania środkami publicznymi na przykładzie środków pochodzących z UE, W: R. Przygodzka (red.), Instrumenty i metody racjonalizacji finansów publicznych. Białystok, s. $123-130$.

7. Kowalski D. (2014), Charakter finansowego wsparcia małych i średnich przedsiębiorstw ze środków publicznych. Kwartalnik Nauk o Przedsiębiorstwie, nr 2, s. 33 - 41.

8. Latoszek E. (red.) (2008), Finansowanie MSP w Polsce ze środków finansowych UE jako czynnik wpływający na konkurencyjność przedsiębiorstw. Warszawa.

9. Lepczyński B., Penczar M. (2013), Znaczenie instrumentów zwrotnych w ograniczaniu luki finansowej i podnoszeniu bezpieczeństwa finansowego przedsiębiorstw z sektora MSP.

10. Obwieszczenie Komisji w sprawie zastosowania art. 87 i 88 Traktatu WE do pomocy państwa w formie gwarancji, Dz. Urz. UE z dnia 20.6.2008 r., C 155, s. 10.

11. Rozporządzenia Komisji (WE) nr 1407/2013 z dnia 18 grudnia 2013 r., w sprawie stosowania art. 107 i 108 Traktatu o Funkcjonowaniu Unii Europejskie do pomocy de minimis, Dz. Urz. UE z 24.12.2013 r., L 352, s. 1.

12. Wolański R. (2013), Wpływ otoczenia finansowego na konkurencyjność małych i średnich przedsiębiorstw. Warszawa.

13. Ustawa z dnia 30 kwietnia 2004 r. o postępowaniu w sprawach dotyczących pomocy publicznej, tj.: Dz. U. z 2007 r. Nr 59 , poz. 404 ze zm.

14. Ustawa z dnia 29 sierpnia 1997 r. Prawo bankowe, tj.: Dz. U. z 2012 r. poz. 1376 ze zm.

15. www.bgk.pl/przedsiebiorstwa/poreczenia-i-gwarancje/gwarancje-de-minimis/informacje-dla-przedsiebiorcow (data dostępu: $1.02 .2017 \mathrm{r}$.$) .$

16. www.bis.org/publ/work207.pdf (data dostępu: 1.02.2017 r.). 